\title{
Ileal digestibility of amino acids and estimates of endogenous amino acid losses in pigs fed wheat, triticale, rye, barley, maize and sorghum
}

\author{
Catherine JONDREVILLE ${ }^{\mathrm{a}, \mathrm{c}}$, Jan VAN DEN BROECKE ${ }^{\mathrm{b}}$, \\ François GÂTEL ${ }^{a *}$, François GrosJeAN ${ }^{\mathrm{a}}$, Sabine VAN CAUWENBERGHE ${ }^{\mathrm{b}}$, \\ Bernard SÈVE ${ }^{\mathrm{c}}$ \\ a Institut Technique des Céréales et des Fourrages, 8 avenue du Président Wilson, \\ 75116 Paris, France \\ b Ajinomoto-Eurolysine, 153 rue de Courcelles, 75817 Paris Cedex 17, France \\ ${ }^{c}$ Institut National de la Recherche Agronomique, Unité Mixte de Recherches sur le Veau et le Porc, \\ 35590 Saint-Gilles, France
}

(Received 5 May 2000; accepted 19 February 2001)

\begin{abstract}
Forty-three batches of cereals (10 of wheat, 10 of triticale, 5 of barley, 5 of rye, 7 of maize and 6 of sorghum) were analysed and studied for their nitrogen (N) and amino acid (AA) ileal digestibility. Each batch was tested on four castrated male pigs, weighing between 30 and $90 \mathrm{~kg}$, and fitted with an end-to-end ileo-rectal anastomosis. Ileal true digestibility (TD) of AA was calculated by correcting ileal apparent digestibility $(\mathrm{AD})$ for basal endogenous AA losses, measured by means of a protein-free diet. Ileal real digestibility (RD) of AA was calculated by correcting AD for total endogenous AA losses, estimated by a multiple regression model. TD of $\mathrm{N}$ and most AA decreased $(P<0.001)$ from wheat, triticale and maize, to barley and sorghum and to rye $(90.3,88.7,89.9$, $85.4,83.7$ and $80.1 \%$, respectively, for the sum of all AA). Estimates of endogenous $\mathrm{N}$ losses decreased $(P<0.001)$ from triticale, sorghum and wheat, to maize, barley and rye (on average 3.10 , $2.93,2.63,2.43,2.27$ and $2.16 \mathrm{~g} \mathrm{~N} \cdot \mathrm{kg}^{-1} \mathrm{DM}$ ingested, respectively). Barley excluded, there was a trend toward increasing endogenous AA losses with increasing dietary acid detergent fibre (ADF) concentration $(r=0.57, P<0.001)$. Barley caused low endogenous $\mathrm{N}$ losses relative to its ADF concentration.
\end{abstract}

cereal / ileal digestibility / endogenous losses / nitrogen / amino acid / pig

Résumé - Digestibilité iléale des acides aminés et estimation des pertes azotées endogènes chez le porc en croissance alimenté à base de blé, de triticale, de seigle, d'orge, de maïs ou de sorgho. Quarante-trois lots de céréales (10 de blé, 10 de triticale, 5 de seigle, 5 d'orge, 7 de maïs et 6 de sorgho) ont fait l'objet d'une analyse chimique et d'une mesure de la digestibilité iléale de

* Correspondence and reprints

Tel.: 33 (0)2 547748 10; fax: 33 (0)2 547229 25; e-mail: fgatel @ itcf.fr 
l'azote $(\mathrm{N})$ et des acides aminés (AA). Chaque lot a été testé sur quatre porcs, mâles, castrés, préparés en anastomose iléo-rectale termino-terminale et pesant entre 30 et $90 \mathrm{~kg}$. La digestibilité iléale vraie (DV) a été calculée en corrigeant la digestibilité iléale apparente (DA) de l'excrétion endogène basale d'AA, mesurée au moyen d'un aliment protéiprive. La digestibilité iléale réelle (DR) a été calculée en corrigeant la DA de l'excrétion endogène totale d'AA, estimée par régression multiple. Les DV les plus élevées $(P<0,001)$ ont été mesurées pour le blé, le triticale et le maïs (respectivement $90,3,88,7,89,9 \%$ pour la somme des AA) et les plus faibles pour le seigle $(80,1 \%$ pour la somme des AA). L'orge et l'avoine présentaient des DV intermédiaires (respectivement 85,4 et 83,7 \% pour la somme des AA). Les pertes endogènes d'azote les plus élevées $(P<0,001)$ ont été estimées pour le triticale, le sorgho et le blé (respectivement $3,10,2,93$ et $2,63 \mathrm{~g} \mathrm{~N} \cdot \mathrm{kg}^{-1}$ matière sèche ingérée (MSI)) et les plus faibles pour le maïs, l'orge et le seigle (respectivement 2,43, 2,27 et 2,16 g N. $\mathrm{kg}^{-1}$ MSI). Orge exclue, les pertes endogènes d'N augmentaient avec la teneur en acid détergent fibre (ADF) de l'aliment $(r=0,57, P<0,001)$. L'excrétion endogène d'azote entrainée par l'ingestion d'orge était faible par rapport à sa teneur en ADF.

céréale / digestibilité iléale / pertes endogènes / azote / acide aminé / porc

\section{INTRODUCTION}

Nitrogen (N) and amino acid (AA) ileal digestibility in cereals for pigs has been widely previously studied by many authors [19, 20, 22, 35, 38, 53]. Data are expressed as ileal apparent, true or real digestibility. Ileal apparent digestibility (AD) values may be strongly biased by the $\mathrm{N}$ and AA content of the experimental diet [17]. The calculation of ileal true digestibility (TD), by correcting AD for basal endogenous losses, is necessary to overcome this methodological problem and to get additive values of digestible AA supply $[20,59]$. The resulting ileal standardised or true digestibility (TD) values have been tabulated for use in practical feed formulation $[10,48,52,55]$. However, there is evidence that total largely exceed basal endogenous gut $\mathrm{N}$ losses. Even corrected for basal endogenous $\mathrm{N}$ losses, ileal $\mathrm{N}$ thus contains variable amounts of specific endogenous $\mathrm{N}$, depending on the characteristics of the feedstuff [12]. Correction of $\mathrm{AD}$ for total endogenous losses leads to ileal real digestibility (RD) according to the terminology proposed by Low [40].

Because 70 to $80 \%$ of gut endogenous secretions are digested and re-absorbed, they largely exceed the observed ileal losses. Moreover, it is established that production of endogenous gut $\mathrm{N}$ involves additional energy and AA costs $[49,59]$. In this respect, the evaluation of dietary factors affecting endogenous $\mathrm{N}$ losses have recently received considerable attention. However, only few authors reported such information for cereals [12, 34, 37, 49].

The current study is part of a more extensive work on ileal digestibility of $\mathrm{N}$ and $\mathrm{AA}$ in pig feeds [30]. The aim was to determine TD of $\mathrm{N}$ and AA and to estimate endogenous gut $\mathrm{N}$ losses in various samples of wheat $(\mathrm{W})$, triticale $(\mathrm{T})$, rye $(\mathrm{R})$, barley $(\mathrm{B})$, maize (M) and sorghum (S) in order to (i) rank the cereal species and (ii) identify dietary factors that contribute to variability in digestibility values and endogenous gut $\mathrm{N}$ losses between samples.

\section{MATERIALS AND METHODS}

\subsection{Feedstuffs and experimental diets}

Forty-three batches of cereals (10 of wheat, 10 of triticale, 5 of barley, 5 of rye, 7 of maize and 6 of sorghum) were studied. Either of pure or mixed cultivars, they were selected in order to be representative of 
cereal batches used for feed in Western Europe. All originated from Western Europe and most of them (thirty-seven) from France. The cultivars are given in Table I. Feedstuffs were ground in a hammer mill fitted with a $2 \mathrm{~mm}$ screen. Per kg, each diet contained $945 \mathrm{~g}$ of cereal and $55 \mathrm{~g}$ of a mineral and vitamin premix to compensate for eliminating the function of the large intestine [64] (Tab. I).

\subsection{Animals and procedures}

The experiments were conducted under the guidelines of the French Ministry of Agriculture for Animal Research. In total, 52 barrows of pure bred Large White or (Large White $\times$ Landrace $) \times($ Large White $\times$ Pietrain) were used in this study. They were surgically prepared with an end-to-end ileorectal anastomosis $[32,51]$ at a body weight (BW) of 25 to $30 \mathrm{~kg}$. Pigs were allowed a four-week recovery period following surgery, and then entered a twelve-week period during which digestibility measurements were made. The experiments lasted from 1990 to 1996 and involved the use of thirteen groups of four pigs, made as similar as possible on the basis of age and BW of the pigs. Each batch of cereal was fed to the four pigs of only one group and at one period; both group and period were selected at random. Therefore, it was assumed that age, breed, BW, or time effects did not influence observed digestibility values.

Animals were fed twice daily ( 8 am and $4 \mathrm{pm}$ ) a diet in meal form mixed with water at the time of feeding (2 volumes water/ 1 volume meal). Drinking water was continuously available. The feeding scale was set at $90 \mathrm{~g}$ meal per $\mathrm{kg}$ metabolic weight $\left(\mathrm{BW}^{0.75}\right)$. Every week, the feed allowance was individually adjusted based on weighings at four-week intervals and projected increases in BW between weighings.

Experimental diets were fed for seven days [22]: an adaptation period of five days followed by a two-day collection period.
This combination of adaptation and collection periods was among those which allowed the most accurate measurement of $\mathrm{N}$ excretion by pigs fitted with an end-to-end ileorectal anastomosis [42]. During the latter period, ileal digesta were totally collected in a plastic reservoir. Twice a day, just after meal, digesta were withdrawn from the reservoir and immediately stored at $4{ }^{\circ} \mathrm{C}$. At the end of the collection period, ileal digesta were pooled per animal, homogenised, and two sub-samples were taken: one was ovendried ( $80{ }^{\circ} \mathrm{C}$ for 72 hours) for dry matter determination, and the other one was freezedried prior to analysis.

\subsection{Chemical analyses}

All chemical analyses were performed in duplicate as previously described [31]. Each batch of cereal, each diet and each pooled sample of ileal digesta were analysed for $\mathrm{N}$ and AA contents. The $\mathrm{N}$ content was measured by the Kjeldahl method. The AA content was determined by chromatography in an ion exchange column, after a 23 -hour hydrolysis in $6 \mathrm{~N} \mathrm{HCl}$ at $110{ }^{\circ} \mathrm{C}$. The sulphur AA content was determined using performic oxidation hydrolysis. Tryptophan was determined by HPLC followed by fluorometric detection, after hydrolysis in an alkaline solution (baryum hydroxide) at $125^{\circ} \mathrm{C}$ for 16 hours.

For each sample of cereal, the dry matter (DM), ash, Neutral Detergent Fibre (NDF), Acid Detergent Fibre (ADF) and Acid Detergent Lignin (ADL), crude fibre (CF), fat and starch contents were determined. The NDF, ADF and ADL determinations were sequentially carried out. The CF was determined according to the Weende method, and starch according to the Ewers method. Crude fat was measured without hydrolysis prior to analysis. The $\mathrm{N}$ content of the NDF residue (NNDF) was evaluated by the successive analysis of NDF and N; it was determined for each batch of cereal except for 5 batches of triticale. The water 
Table I. Analytical characteristics of the cereal grains (in $\mathrm{g} \cdot \mathrm{kg}^{-1} \mathrm{DM}$ except $\mathrm{NNDF}^{1}$ and WERV${ }^{2}$ ).

\begin{tabular}{|c|c|c|c|c|c|c|c|c|c|c|c|c|}
\hline & $\mathrm{N}$ & Fat & $\mathrm{CF}$ & Ash & NDF & $\mathrm{ADF}$ & ADL & NNDF & Starch & Sol. AX & Sol. $\beta$-gluc & WERV \\
\hline \multicolumn{13}{|c|}{ Wheat $\left(n^{4}=10\right)$} \\
\hline $\mathrm{m}^{3}$ & 22.5 & 19.5 & 25.8 & 19.1 & 126.1 & 31.3 & 9.0 & 9.7 & 682.6 & 5.5 & 1.0 & 1.6 \\
\hline $\mathrm{sd}^{3}$ & 2.28 & 5.49 & 3.43 & 1.82 & 16.28 & 3.69 & 0.93 & 1.46 & 24.80 & 1.37 & 0.22 & 0.25 \\
\hline $\min ^{3}$ & 19.9 & 14.4 & 22.4 & 16.1 & 111.6 & 26.5 & 7.3 & 7.3 & 618.1 & 4.0 & 0.6 & 1.2 \\
\hline $\max ^{3}$ & 27.1 & 33.9 & 33.2 & 21.5 & 159.3 & 37.3 & 10.2 & 12.7 & 704.9 & 7.7 & 1.2 & 2.1 \\
\hline \multicolumn{13}{|c|}{ Triticale $(n=10)$} \\
\hline $\mathrm{m}$ & 19.0 & 16.0 & 26.5 & 21.1 & 126.3 & 32.3 & 8.6 & 7.7 & 684.7 & 6.1 & 1.1 & 1.9 \\
\hline $\mathrm{sd}$ & 3.00 & 0.91 & 3.46 & 1.34 & 13.59 & 3.79 & 1.48 & 1.54 & 19.13 & 1.20 & 0.35 & 0.41 \\
\hline $\min$ & 15.0 & 14.3 & 19.9 & 18.7 & 103.5 & 26.7 & 7.0 & 6.7 & 648.1 & 4.0 & 0.7 & 1.4 \\
\hline $\max$ & 24.1 & 17.6 & 29.8 & 23.1 & 144.8 & 36.4 & 12.0 & 10.3 & 711.8 & 7.8 & 1.9 & 2.5 \\
\hline \multicolumn{13}{|c|}{ Rye $(n=5)$} \\
\hline $\mathrm{m}$ & 15.4 & 16.2 & 21.3 & 19.8 & 136.2 & 27.6 & 8.5 & 13.2 & 648.6 & 13.7 & 3.6 & 5.8 \\
\hline $\mathrm{sd}$ & 1.20 & 1.11 & 1.47 & 0.64 & 9.52 & 3.48 & 0.70 & 0.92 & 11.65 & 1.78 & 0.64 & 0.98 \\
\hline $\min$ & 13.9 & 15.1 & 19.6 & 19.1 & 123.9 & 24.1 & 7.9 & 11.7 & 635.9 & 12.4 & 2.9 & 4.9 \\
\hline $\max$ & 16.8 & 17.8 & 23.4 & 20.6 & 150.2 & 32.9 & 9.7 & 13.9 & 663.8 & 16.8 & 4.0 & 7.1 \\
\hline \multicolumn{13}{|c|}{ Barley $(n=5)$} \\
\hline $\mathrm{m}$ & 21.0 & 25.0 & 47.8 & 26.3 & 184.3 & 53.2 & 8.1 & 8.6 & 569.9 & 4.4 & 17.3 & 5.7 \\
\hline sd & 1.19 & 5.62 & 10.67 & 2.89 & 20.70 & 10.03 & 0.98 & 1.00 & 46.47 & 1.09 & 5.08 & 2.78 \\
\hline $\min$ & 20.0 & 21.6 & 34.1 & 22.8 & 159.5 & 45.0 & 6.8 & 7.8 & 496.1 & 3.4 & 10.5 & 1.4 \\
\hline $\max$ & 22.4 & 34.9 & 60.0 & 29.6 & 211.2 & 64.8 & 9.3 & 9.9 & 609.8 & 6.0 & 24.4 & 8.0 \\
\hline \multicolumn{13}{|c|}{ Maize $(n=7)$} \\
\hline $\mathrm{m}$ & 16.7 & 44.6 & 22.6 & 15.1 & 97.5 & 24.4 & 2.6 & 6.8 & 716.3 & 0.8 & 0.4 & 1.1 \\
\hline $\mathrm{sd}$ & 2.39 & 5.49 & 4.44 & 1.46 & 5.91 & 1.77 & 1.30 & 0.99 & 23.35 & 0.10 & 0.21 & 0.04 \\
\hline $\min$ & 13.2 & 39.2 & 18.9 & 12.4 & 89.9 & 22.1 & 0.8 & 5.6 & 693.5 & 0.6 & 0.2 & 1.0 \\
\hline $\max$ & 20.2 & 53.4 & 32.3 & 17.3 & 108.6 & 26.8 & 4.2 & 8.0 & 764.3 & 0.9 & 0.8 & 1.1 \\
\hline \multicolumn{13}{|c|}{ Sorghum $(n=6)$} \\
\hline $\mathrm{m}$ & 17.9 & 35.3 & 22.5 & 15.3 & 83.7 & 28.4 & 4.9 & 9.6 & 763.0 & 2.0 & 0.7 & 1.0 \\
\hline $\mathrm{sd}$ & 1.74 & 1.73 & 3.08 & 1.46 & 9.59 & 2.28 & 0.68 & 1.70 & 17.61 & 1.68 & 0.47 & 0.05 \\
\hline $\min$ & 15.2 & 33.3 & 19.1 & 14.1 & 73.2 & 25.5 & 4.2 & 7.2 & 740.6 & 0.5 & 0.2 & 1.0 \\
\hline $\max$ & 20.1 & 37.9 & 27.7 & 17.8 & 96.2 & 31.9 & 6.0 & 11.4 & 781.7 & 4.1 & 1.4 & 1.1 \\
\hline
\end{tabular}

${ }^{1} \mathrm{~N}$ bound to NDF (\% total $\mathrm{N}$ in the grain).

${ }^{2}$ Water Extract Relative Viscosity.

${ }^{3} \mathrm{~m}$ : mean value for the cereal species; sd: standard deviation; min: minimum value; max: maximum value.

${ }^{4}$ Number of batches - Wheat: for Sol. AX, Sol. $\beta$-gluc. and WERV $(n=9)$ - Triticale: for NNDF $(n=5)-\operatorname{Rye}$ : for Sol. $\beta$-gluc. $(n=2)$ - Barley: for CF $(n=4)$ - Cultivars: Wheat: four batches of mixed cultivars, one of Thésée; one of Beaver, one of Ritmo, one of Slepjner, two of Apollo; Triticale: one batch of Dagro, one of Aubrac, one of Magistral, one of Trimaran, two of Newton, two of Trick, two of Alamo; Rye: five batches of mixed cultivars; Barley: two batches of mixed 2-row cultivars, one of mixed 6-row cultivars, one of Express (6-row, winter), one of Magie (2-row, winter); Maize: 5 batches of mixed cultivars, one of Dea, one of Volga; Sorghum: one batch of mixed white cultivars, one of DK 34 (red), one of DK26 (red), one of Taxus (white), two of Aralba (white). The mineral and vitamin premix supplied per kg DM feed: $303 \mathrm{mg} \mathrm{MgCl} 2.6 \mathrm{H}_{2} \mathrm{O} ; 303 \mathrm{mg} \mathrm{KCl} ; 8437 \mathrm{mg}$ $\mathrm{NaCl} ; 22000 \mathrm{mg} \mathrm{NaHCO}$; $9548 \mathrm{mg} \mathrm{CaHPO}_{4} ; 10849 \mathrm{mg} \mathrm{CaCO} ; 512 \mathrm{mg} ; \mathrm{FeSO}_{4} .7 \mathrm{H}_{2} \mathrm{O} ; 303 \mathrm{mg} \mathrm{ZnSO}$. $1 \mathrm{H}_{2} \mathrm{O}$; $80 \mathrm{mg} \mathrm{CuSO} \mathrm{CH}_{4} .5 \mathrm{H}_{2} \mathrm{O} ; 121 \mathrm{mg} \mathrm{MnSO}_{4} .1 \mathrm{H}_{2} \mathrm{O} ; 5 \mathrm{mg} \mathrm{CoCO} ; 2 \mathrm{mg} \mathrm{Ca}\left(\mathrm{IO}_{3}\right)_{2} ; 27500 \mathrm{IU}$ vit. A; $2200 \mathrm{IU}$ vit. $\mathrm{D}_{3}$; $4070 \mathrm{IU}$ vit. $\mathrm{E} ; 21 \mathrm{mg}$ vit. $\mathrm{K}_{3} ; 6 \mathrm{mg}$ vit. $\mathrm{B}_{1} ; 14 \mathrm{mg}$ vit. $\mathrm{B}_{2} ; 13 \mathrm{mg}$ vit. $\mathrm{B}_{6} ; 51 \mathrm{mg}$ vit. $\mathrm{PP} ; 80 \mathrm{mg}$ vit. C; $1 \mathrm{mg}$ folic acid; $70 \mathrm{mg}$ vit. $\mathrm{B}_{12} ; 0.03 \mathrm{mg}$ biotin; $30 \mathrm{mg}$ vit. $\mathrm{B}_{3} ; 804 \mathrm{mg}$ choline; $50 \mathrm{mg}$ carbadox. 
extract viscosity was measured by means of a capillary viscosimeter (AVS 310, Schott Geräte, Germany). To get the water extract, a suspension of ground grain in water was centrifuged (10 minutes, $5000 \mathrm{~g}$ ) at room temperature. The supernatant was heated at $100{ }^{\circ} \mathrm{C}$, centrifuged ( 5 minutes, $5000 \mathrm{~g}$ ), filtrated over a $0.45 \mu \mathrm{m}$ membrane and stored at $0{ }^{\circ} \mathrm{C}$ [23]. The water extract relative viscosity (WERV) was calculated as the ratio of the cereal water extract falling time to the de-ionised water falling time. The soluble arabinoxylans (Sol. AX) concentration was measured by colorimetry [54] by means of a colorimeter (Evolution II, Alliance Instrument, France). The Soluble $\beta$-glucans (Sol. $\beta$-gluc.) content was measured after enzymatic hydrolysis [43], by measuring the absorbance at $\lambda=0.510 \mu \mathrm{m}$ (UVIKON 930, Kontron Instrument, France). In sorghum, tannins content determination was based on the reaction between ferric (III) ammonium citrate and polyphenols, after extraction by dimethylformamide. The concentration was measured by spectrophotometry $(\lambda=0.525 \mu \mathrm{m})$ (UVIKON 930, Kontron Instrument, France), taking tannic acid as standard [1].

\subsection{Calculations}

\subsubsection{Estimates of endogenous gut AA losses}

First, the proportions of endogenous and of dietary proteins in ileal digesta were estimated according to a mathematical model. This model allows the calculation of proportions of different 'reference' proteins in a mixture, from their AA profiles [14]. The method combines a multiple regression analysis, without intercept, and the calculation of the deviation between the observed and expected AA composition of a mixture of proteins by means of a chi-square $\left(\chi^{2}\right)$ value. It was previously used to calculate the proportions of endogenous and exogenous proteins in ileal digesta from pigs fed different feedstuffs and provided estimates comparable to measured values obtained by ${ }^{15} \mathrm{~N}$ dilution using an intravenous

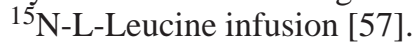

A combination of the $n$ following equations was used to estimate the contributions of various 'reference' proteins in digesta protein collected from the distal ileum:

$$
\begin{aligned}
\mathrm{AA}_{1, \text { digesta }}= & \mathrm{x}_{1} \mathrm{AA}_{1, \mathrm{P} 1}+\ldots+\ldots+\mathrm{x}_{\mathrm{k}} \\
& \mathrm{AA}_{1, \mathrm{Pk}}+\ldots \ldots+\mathrm{x}_{\mathrm{m}} \mathrm{AA}_{1, \mathrm{Pm}} \\
\mathrm{AA}_{\mathrm{i}, \text { digesta }}= & \mathrm{x}_{1} \mathrm{AA}_{\mathrm{i}, \mathrm{P} 1}+\ldots+\mathrm{x}_{\mathrm{k}} \\
& \mathrm{AA}_{\mathrm{i}, \mathrm{Pk}}+\ldots \ldots+\mathrm{x}_{\mathrm{m}} \mathrm{AA}_{\mathrm{i}, \mathrm{Pm}} \\
\mathrm{AA}_{\mathrm{n}, \text { digesta }}= & \mathrm{x}_{1} \mathrm{AA}_{\mathrm{n}, \mathrm{P} 1}+\ldots+\mathrm{x}_{\mathrm{k}} \\
& \mathrm{AA}_{\mathrm{n}, \mathrm{Pk}}+\ldots \ldots+\mathrm{x}_{\mathrm{m}} \mathrm{AA}_{\mathrm{n}, \mathrm{Pm}}
\end{aligned}
$$

where $n=16$, number of assayed amino acids; $\mathrm{AA}_{\mathrm{i} \text {,digesta }}=\%$ of $\mathrm{AA}_{\mathrm{i}}$ in digesta protein; $\mathrm{P}_{\mathrm{k}}=$ 'reference' protein $\mathrm{k} ; \mathrm{AA}_{\mathrm{i}, \mathrm{Pk}}=\%$ of $\mathrm{AA}_{\mathrm{i}}$ in 'reference' protein $\mathrm{k} ; \mathrm{x}_{1}, \mathrm{x}_{\mathrm{k}} \ldots \mathrm{x}_{\mathrm{m}}$ $=$ regression coefficients of the actual $\mathrm{AA}$ profile when regressing digesta protein on the 'reference' proteins $\mathrm{P}_{1} \ldots \mathrm{P}_{\mathrm{m}}$.

In order to assign the same weight to each AA, the square-root of the AA proportions in digesta protein were considered as dependent variables, the ratio of AA proportions in 'reference' proteins to this square-root being considered as independent variables. The $\chi^{2}$ value, representing the extent of the agreement between the determined and the expected AA composition of digesta protein was calculated as follows:

$\chi^{2}=n \times \sum_{\mathrm{i}=1}^{n} \frac{\left(\mathrm{AA}_{\mathrm{i}, \text { digesta }}-\mathrm{AA}_{\mathrm{i}, \text { mixture }}\right)^{2}}{\left(\mathrm{AA}_{\mathrm{i}, \text { digesta }}-\mathrm{AA}_{\mathrm{i}, \text { mixture }}\right)^{2 / 2}}$

where $\mathrm{AA}_{\mathrm{i} \text { digesta }}=\%$ of $\mathrm{AA}_{\mathrm{i}}$ in actual protein digesta; $\mathrm{AA}_{\mathrm{i} \text {,mixture }}=\%$ of $\mathrm{AA}_{\mathrm{i}}$ in the mixture of 'reference' proteins.

The AA compositions of the various proteins were expressed as percentages of the sum of the analysed AA contents. For the calculations, tryptophan, not determined in residual protein of NDF, and proline, not determined in our AA analyses, were not considered. The endogenous protein, whole dietary protein and residual protein of NDF were used as 'reference' proteins. The AA composition of the endogenous protein has 
been obtained from the determination of basal endogenous AA losses (Bendo), previously performed in our laboratory (unpublished results), using twenty pigs prepared and managed according to the above described procedure and fed a protein-free diet made of maize starch $(58 \%)$, sucrose $(30 \%)$, wood cellulose $(3.5 \%)$, soya oil $(3.0 \%)$, and the mineral and vitamin premix used for experimental diets $(5.5 \%)$. The AA composition of the protein of NDF for each species was available in the literature [34, 41]. It was introduced in the model because it was likely to be poorly digestible due to the restricted access of digestive enzymes to protein encapsulated by fibre [58] Regression analyses were performed using the STEPWISE procedure of the MINITAB statistical software [45].

Total endogenous AA losses $\left(\mathrm{g} \cdot \mathrm{kg}^{-1}\right.$ DMI) were calculated as follows:

$$
\text { Tendo }=\mathrm{x}_{\text {Endo }} \times \text { Texcreted }
$$

where Tendo = estimates of total endogenous AA losses $\left(\mathrm{g} \cdot \mathrm{kg}^{-1} \mathrm{DMI}\right) ; \mathrm{x}_{\text {Endo }}=$ estimated proportion of endogenous protein in the digesta protein; Texcreted = total AA excretion with digesta $\left(\mathrm{g} \cdot \mathrm{kg}^{-1} \mathrm{DMI}\right)$.

\subsubsection{Digestibility calculation}

Ileal apparent digestibility (AD) was calculated from $\mathrm{N}$ and AA concentrations in diets and in ileal digesta. For ileal true digestibility (TD) calculation, it was corrected for basal endogenous AA losses (Bendo) [40]. The assumption was made that the basal endogenous losses were directly related to DM intake (DMI):

$$
\begin{aligned}
& \mathrm{TD}=\mathrm{AD}+\text { Bendo }\left(\mathrm{g} \cdot \mathrm{kg}^{-1} \mathrm{DMI}\right) \\
& \times 100 / \mathrm{AA} \text { ingested }\left(\mathrm{g} \cdot \mathrm{kg}^{-1} \mathrm{DMI}\right) .
\end{aligned}
$$

This correction of AD to TD was aimed at reducing the effects of $\mathrm{N}$ and $\mathrm{AA}$ content of the experimental diets on the digestibility values $[17,59]$.

Real ileal digestibility (RD) was calculated by correcting $\mathrm{AD}$ for total endogenous

$$
\begin{gathered}
\text { AA losses (Tendo) }\left(\mathrm{g} \cdot \mathrm{kg}^{-1} \mathrm{DMI}\right)[40] \text { : } \\
\quad \mathrm{RD}=\mathrm{AD}+\text { Tendo }\left(\mathrm{g} \cdot \mathrm{kg}^{-1} \mathrm{DMI}\right) \\
\times 100 / \mathrm{AA} \text { ingested }\left(\mathrm{g} \cdot \mathrm{kg}^{-1} \mathrm{DMI}\right)
\end{gathered}
$$

\subsubsection{Data analysis}

The effect of the batch (B) on total endogenous AA losses ( $\left.\mathrm{g} \cdot \mathrm{kg}^{-1} \mathrm{DMI}\right)$, as well as on TD and RD of $\mathrm{N}$ and AA was first analysed within each cereal species. An overall analysis of variance was performed to evaluate the effect of the species relative to the residual variation between batches. The overall model included the following items: the cereal species (S) and the batch nested within species $B(S)$. The effect of species (S) was tested against batch nested within species $(\mathrm{B}(\mathrm{S}))$. A Tukey's Studentized Range test was used for comparison of means. Analyses of variance were performed using the GLM procedure of the SAS statistical software [56].

\section{RESULTS}

The average BW of pigs fed wheat, rye and sorghum were in the same range (44 to $69 \mathrm{~kg}$ ). It was slightly lower for triticale (34 to $55 \mathrm{~kg}$ ), higher for barley (57 to $80 \mathrm{~kg}$ ) and more variable for maize (39 to $85 \mathrm{~kg}$ ).

\subsection{Chemical characteristics of the cereal batches}

Both the fibre (NDF, ADF, ADL, CF) concentration and its variability among batches increased from sorghum and maize to wheat, triticale and rye, and to barley (Tab. I). The lowest $\mathrm{N}$ concentrations were measured for rye, maize and sorghum. The proportion of the total $\mathrm{N}$ located in the NDF residue (NNDF) was almost two times higher in rye than in maize (13.2 and 6.8\% of the total $\mathrm{N}$, respectively). This proportion was on average $9 \%$ for the other species, with a high variability within 
species. The average soluble arabinoxylans concentration in rye was roughly two times higher than in wheat and triticale (13.7, 5.5 and $6.1 \mathrm{~g} \cdot \mathrm{kg}^{-1} \mathrm{DM}$, respectively). The content of soluble $\beta$-glucans in barley ranged from 10.5 to $24.4 \mathrm{~g} \cdot \mathrm{kg}^{-1} \mathrm{DM}$. Water extract relative viscosity increased from maize and sorghum (1.0 to 1.1$)$ to wheat and triticale (1.6 and 1.9, respectively) and to barley and rye (5.7 and 5.8, respectively). All the sorghum batches were tannin-free $(<0.5 \mathrm{~g}$ tannins per kg DM).

Tryptophan, methionine, cystine and histidine were among scarce amino acids, irrespective of the grain (Tab. II). Glutamic acid displayed by far the highest concentration, followed, although to a lesser extent, by leucine and aspartic acid. Leucine

Table II. Amino acid content of the grains $\left(\mathrm{g} \cdot 16 \mathrm{~g}^{-1} \mathrm{~N}\right)$.

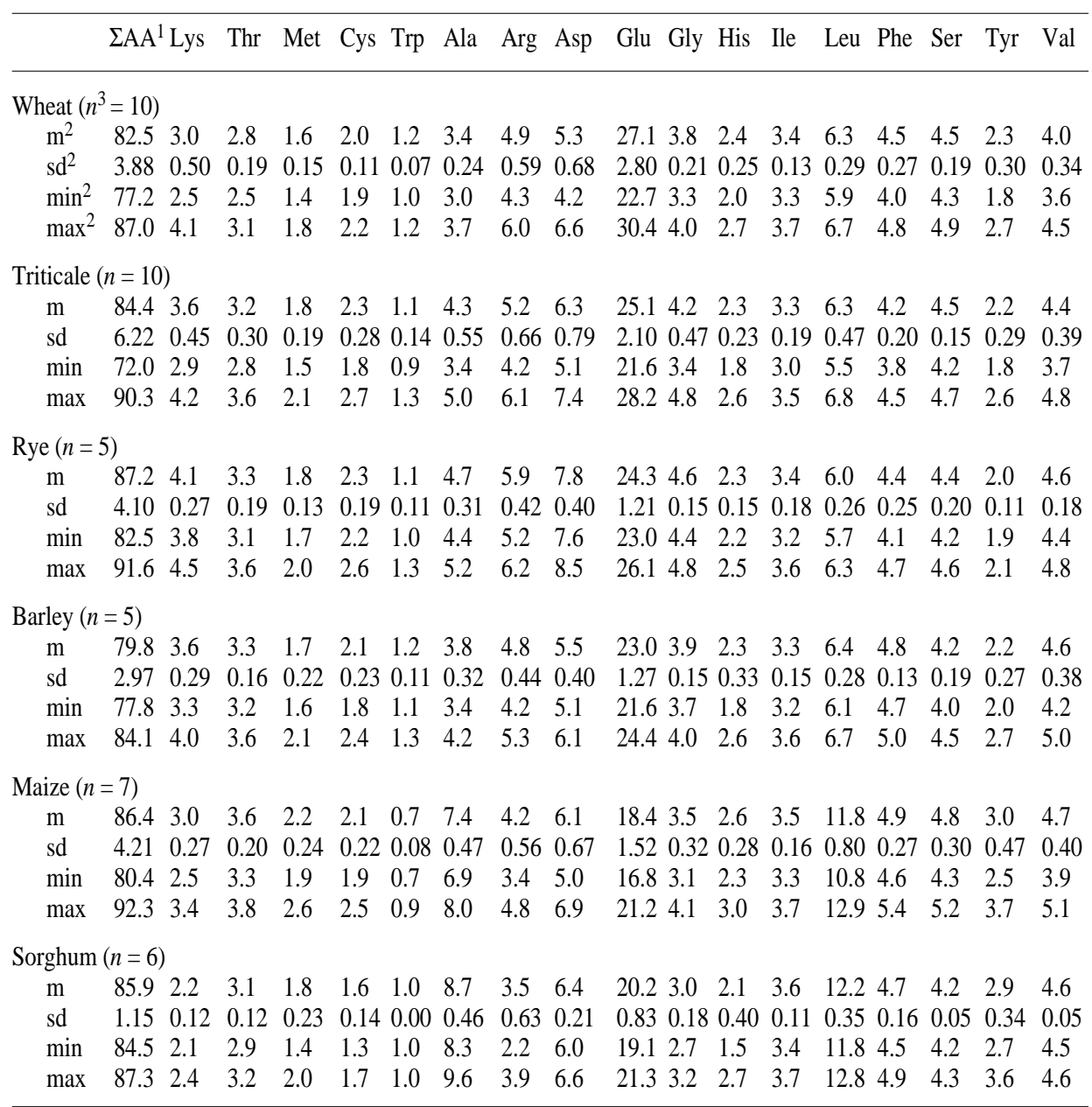

${ }^{1}$ Sum of all amino acids.

${ }^{2} \mathrm{~m}$ : mean value for the cereal species; sd: standard deviation; min: minimum value; max: maximum value.

${ }^{3}$ Number of batches. 
concentration was particularly high in maize and in sorghum.

\subsection{Estimates of endogenous $\mathrm{N}$ losses}

For all the batches of cereal, except those of sorghum, the introduction of endogenous protein with protein bound to NDF in the model allowed the $\chi^{2}$ distance between the determined and the expected proteins to be minimised. Except for one batch of wheat and four batches of triticale, both endogenous protein and protein bound to NDF were introduced $(P<0.05)$ in the model. For these five batches the probability for the introduction of protein bound to NDF in the model was below 0.10 (results not shown). For the sorghum batches, both the dietary protein and the protein bound to NDF were introduced in the model $(P<0.01$ and $P<0.05$, respectively), but the $\chi^{2}$ distance was minimised with the dietary protein $\left(\chi^{2}=3\right.$ to 84 vs. 45 to 131). The estimated proportion of total endogenous protein in digesta protein reached an average of $70 \%$ for triticale, $65 \%$ for maize, $60 \%$ for wheat, $55 \%$ for sorghum and $40 \%$ for rye and barley.

Differences $(P<0.05)$ between batches for total endogenous AA losses ( $\left.\mathrm{g} \cdot \mathrm{kg}^{-1} \mathrm{DMI}\right)$ were observed in wheat, barley and maize (results not shown). Clear effects $(P<0.001)$ of the species were detected (Tab. III). The highest estimates were calculated for triticale (10.7 $\left.\mathrm{g} \cdot \mathrm{kg}^{-1} \mathrm{DMI}\right)$, and the lowest for maize, barley and rye $\left(8.44,7.88\right.$ and $7.50 \mathrm{~g} \cdot \mathrm{kg}^{-1}$ DMI, respectively). Intermediate estimates were calculated for wheat and sorghum (9.12 and $9.83 \mathrm{~g} \cdot \mathrm{kg}^{-1} \mathrm{DMI}$, respectively).

\subsection{TD and RD of $\mathrm{N}$ and $A A$}

Batches differed $(P<0.05)$ for TD of most $\mathrm{AA}$ in all species and for RD of most AA in all species except rye and sorghum (results not shown). A clear effect $(P<0.001)$ of the species was observed for TD and RD, irrespective of AA (Tabs. III and IV). Both TD and RD of $\mathrm{N}$ and most AA decreased from wheat, triticale and maize to sorghum and barley, and to rye. In wheat, triticale and maize, the TD and RD of the sum of all AA were $90 \%$ and $95 \%$, respectively. Both measures decreased by 5 percentage units in comparison to sorghum and barley and by 5 additional percentage units to rye.

\section{DISCUSSION}

\subsection{Chemical characteristics}

The variation in major nutrients within whole grain cereals found in our study was to the same extent as reported in the literature $[2,16,19,25,44]$. According to these authors, in addition to variety, location, crop husbandry and year of harvest may affect the composition of cereals.

In agreement with data reported in the literature [2], soluble $\beta$-glucans were minor constituents of wheat and maize, whereas their concentration was slightly higher in rye and reached the maximum level in barley. The concentration of soluble arabinoxylans was in the following order: maize $<$ wheat and barley < rye. The same order was reported previously [2]. The ranking of the different cereal species for water extract relative viscosity, and the range of variability within cereal species were in agreement with previous observations [24]. The low levels of tannins in the sorghum batches was in accordance with the results obtained for most cultivars nowadays grown in Western Europe [25, 44]. All the cereal batches matched globally the AA concentrations provided in the European Amino Acid Table [62].

\subsection{True digestibility values and estimates of endogenous AA losses}

The manner in which the ileal digestibility measurements were obtained raises the question of the impact of the characteristics 
Table III. Effect of the cereal species ${ }^{1}$ on endogenous AA losses and ileal real digestibility of $\mathrm{N}$ and AA.

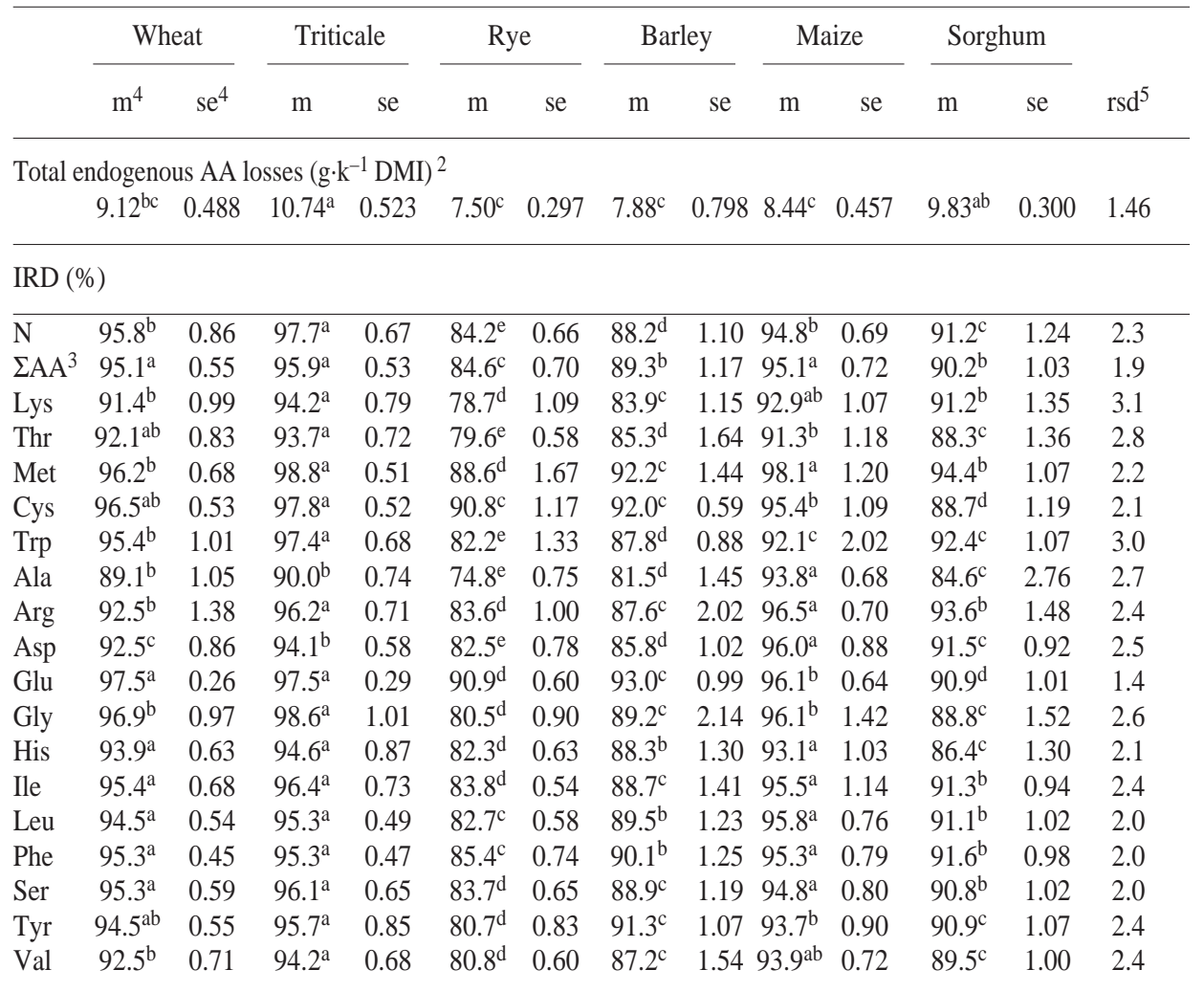

${ }^{1}$ The effect of the species, tested against the batch nested within the species is always highly significant $(P<0.001)$ Values with different superscript in the same row differ significantly at $P<0.05$.

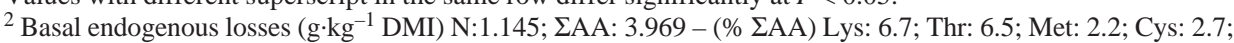
Ala: 7.5; Arg: 5.2; Asp: 10.6; Glu: 13.2; Gly: 10.4; His: 2.3; Ile: 5.0; Leu: 7.6; Phe: 4.2; Ser: 6.4; Tyr: 2.8; Val: 6.7

${ }^{3}$ Sum of all amino acids.

${ }^{4} \mathrm{~m}$ : mean value; se: standard error.

5 rsd: residual standard deviation.

of the groups of growing pigs on differences between samples. However, there is no indication in the literature of factors causing significant variation in the ileal digestibility of the AA other than those associated with changes in dietary components.

The feedstuffs were tested within a relatively broad range of BW. Long term effects of end-to-end ileo-rectal anastomosis, such as histological changes in the ileum and increased concentration of volatile fatty acids due to bacterial fermentation in the digesta has been reported previously [18]. Nevertheless, these changes may affect ileal digestibility of organic matter and particularly that of fibre, but not that of $\mathrm{N}$ and AA $[5,18,33]$. However, endogenous $\mathrm{N}$ losses $\left(\mathrm{g} \cdot \mathrm{kg}^{-1} \mathrm{DMI}\right)$ may decrease with the increase in the animal BW between 45 and $80 \mathrm{~kg}$ [26, 27]. Possibly, this decrease occurred in our study and biased the ranking of species. In particular, the average 
T able IV. Effect of the cereal species ${ }^{1}$ on ileal true digestibility ${ }^{2}$ of $\mathrm{N}$ and AA.

\begin{tabular}{|c|c|c|c|c|c|c|c|c|c|c|c|c|c|}
\hline & \multicolumn{2}{|c|}{ Wheat } & \multicolumn{2}{|c|}{ Triticale } & \multicolumn{2}{|c|}{ Rye } & \multicolumn{2}{|c|}{ Barley } & \multicolumn{2}{|c|}{ Maize } & \multicolumn{2}{|c|}{ Sorghum } & \multirow[b]{2}{*}{$\mathrm{rsd}^{5}$} \\
\hline & $\mathrm{m}^{4}$ & $\mathrm{se}^{4}$ & $\mathrm{~m}$ & se & $\mathrm{m}$ & se & $\mathrm{m}$ & se & $\mathrm{m}$ & se & $\mathrm{m}$ & se & \\
\hline $\mathrm{N}$ & $88.9^{\mathrm{a}}$ & 0.63 & $86.6^{\mathrm{b}}$ & 0.64 & $77.3^{d}$ & 0.54 & $82.7^{\mathrm{c}}$ & 1.13 & $86.7^{\mathrm{b}}$ & 0.76 & $81.2^{\mathrm{c}}$ & 1.10 & 1.8 \\
\hline$\Sigma \mathrm{AA}^{3}$ & $90.3^{\mathrm{a}}$ & 0.40 & $88.7^{\mathrm{b}}$ & 0.35 & $80.1^{\mathrm{e}}$ & 0.67 & $85.4^{\mathrm{c}}$ & 0.77 & $89.9^{\mathrm{a}}$ & 0.83 & $83.7^{\mathrm{d}}$ & 0.99 & 1.6 \\
\hline Lys & $82.9^{\mathrm{a}}$ & 0.82 & $83.0^{\mathrm{a}}$ & 0.45 & $72.5^{\mathrm{c}}$ & 1.12 & $78.0^{\mathrm{b}}$ & 0.94 & $83.4^{\mathrm{a}}$ & 1.26 & $74.4^{c}$ & 2.09 & 2.9 \\
\hline Thr & $83.4^{\mathrm{a}}$ & 0.45 & $81.5^{\mathrm{b}}$ & 0.56 & $72.2^{\mathrm{e}}$ & 0.43 & $79.2^{\mathrm{c}}$ & 1.02 & $83.3^{\mathrm{a}}$ & 1.41 & $76.7^{\mathrm{d}}$ & 1.62 & 2.5 \\
\hline Met & $90.8^{\mathrm{b}}$ & 0.43 & $91.5^{\mathrm{b}}$ & 0.27 & $83.7^{\mathrm{d}}$ & 1.82 & $88.2^{c}$ & 0.82 & $93.5^{\mathrm{a}}$ & 1.16 & $87.6^{\mathrm{c}}$ & 1.37 & 2.0 \\
\hline Cys & $91.5^{\mathrm{a}}$ & 0.40 & $90.9^{\mathrm{ab}}$ & 0.28 & $86.3^{c}$ & 1.38 & $88.0^{c}$ & 0.49 & $89.6^{\mathrm{b}}$ & 1.00 & $79.4^{\mathrm{d}}$ & 1.25 & 1.8 \\
\hline $\operatorname{Trp}$ & $88.6^{\mathrm{a}}$ & 0.77 & $86.6^{\mathrm{b}}$ & 0.63 & $75.4^{\mathrm{e}}$ & 1.41 & $82.4^{\mathrm{c}}$ & 1.22 & $79.5^{\mathrm{d}}$ & 1.32 & $81.2^{\mathrm{cd}}$ & 1.05 & 2.5 \\
\hline Ala & $80.8^{\mathrm{b}}$ & 0.91 & $79.4^{\mathrm{b}}$ & 0.69 & $68.6^{\mathrm{d}}$ & 0.61 & $75.4^{\mathrm{c}}$ & 0.95 & $89.2^{\mathrm{a}}$ & 0.91 & $80.0^{\mathrm{b}}$ & 2.67 & 2.8 \\
\hline Arg & $88.6^{\mathrm{b}}$ & 1.03 & $90.2^{\mathrm{a}}$ & 0.45 & $80.4^{\mathrm{d}}$ & 0.96 & $84.5^{\mathrm{c}}$ & 1.45 & $91.4^{\mathrm{a}}$ & 0.67 & $84.7^{\mathrm{c}}$ & 2.79 & 2.0 \\
\hline Asp & $84.7^{\mathrm{b}}$ & 0.57 & $84.0^{\mathrm{bc}}$ & 0.56 & $77.3^{\mathrm{e}}$ & 0.94 & $79.9^{d}$ & 0.30 & $88.6^{\mathrm{a}}$ & 1.01 & $82.4^{\mathrm{c}}$ & 0.92 & 2.3 \\
\hline Glu & $95.7^{\mathrm{a}}$ & 0.28 & $94.4^{\mathrm{b}}$ & 0.21 & $88.8^{\mathrm{e}}$ & 0.59 & $91.2^{\mathrm{d}}$ & 0.83 & $92.9^{c}$ & 0.71 & $87.4^{\mathrm{f}}$ & 0.94 & 1.2 \\
\hline Gly & $86.4^{\mathrm{a}}$ & 0.58 & $84.0^{\mathrm{b}}$ & 0.42 & $71.9^{\mathrm{d}}$ & 0.71 & $81.0^{c}$ & 1.11 & $83.2^{\mathrm{bc}}$ & 1.95 & $70.0^{\mathrm{d}}$ & 1.41 & 3.1 \\
\hline His & $90.2^{\mathrm{a}}$ & 0.55 & $88.6^{\mathrm{b}}$ & 0.72 & $78.6^{\mathrm{d}}$ & 0.43 & $85.3^{\mathrm{c}}$ & 1.33 & $89.0^{\mathrm{ab}}$ & 0.95 & $80.2^{\mathrm{d}}$ & 2.03 & 1.7 \\
\hline Ile & $89.8^{\mathrm{a}}$ & 0.53 & $87.4^{\mathrm{b}}$ & 0.42 & $78.3^{\mathrm{d}}$ & 0.56 & $84.3^{c}$ & 1.10 & $89.2^{\mathrm{a}}$ & 0.95 & $83.7^{\mathrm{c}}$ & 0.93 & 1.9 \\
\hline Leu & $89.8^{\mathrm{b}}$ & 0.44 & $88.1^{\mathrm{c}}$ & 0.42 & $77.9^{\mathrm{e}}$ & 0.64 & $85.8^{\mathrm{d}}$ & 0.89 & $92.8^{\mathrm{a}}$ & 0.77 & $87.7^{\mathrm{c}}$ & 0.97 & 1.7 \\
\hline Phe & $91.7^{\mathrm{a}}$ & 0.46 & $89.2^{\mathrm{b}}$ & 0.43 & $81.7^{\mathrm{d}}$ & 0.62 & $87.3^{\mathrm{c}}$ & 1.12 & $91.5^{\mathrm{a}}$ & 0.81 & $86.7^{\mathrm{c}}$ & 0.96 & 1.7 \\
\hline Ser & $89.9^{\mathrm{a}}$ & 0.43 & $87.6^{\mathrm{b}}$ & 0.43 & $78.2^{\mathrm{e}}$ & 0.43 & $84.2^{c}$ & 0.70 & $88.9^{\mathrm{a}}$ & 1.06 & $82.6^{\mathrm{d}}$ & 1.03 & 1.7 \\
\hline Tyr & $89.9^{\mathrm{a}}$ & 0.46 & $88.2^{\mathrm{bc}}$ & 0.52 & $74.9^{\mathrm{e}}$ & 1.01 & $87.4^{\mathrm{c}}$ & 0.90 & $89.4^{\mathrm{ab}}$ & 1.03 & $85.7^{\mathrm{d}}$ & 1.07 & 2.0 \\
\hline Val & $86.1^{\mathrm{b}}$ & 0.61 & $85.0^{\mathrm{b}}$ & 0.42 & $75.2^{\mathrm{d}}$ & 0.60 & $82.7^{\mathrm{c}}$ & 1.00 & $87.5^{\mathrm{a}}$ & 0.70 & $81.4^{\mathrm{c}}$ & 1.06 & 2.0 \\
\hline
\end{tabular}

${ }^{1}$ The effect of the species, tested against the batch nested within the species was always highly significant $(P<0.001)$. Values with different superscript in the same row differ significantly at $P<0.05$.

${ }^{2}$ Expressed as percentage units.

${ }^{3}$ Sum of all amino acids.

${ }_{5}^{4} \mathrm{~m}$ : mean value; se: standard error.

${ }^{5}$ rsd: residual standard deviation.

estimates of total endogenous AA losses for triticale, offered to pigs of 34 to $55 \mathrm{~kg} \mathrm{BW}$, may have been overestimated compared to the other species.

Our method for estimating total endogenous AA losses relied on the assumptions that the AA composition of the 'reference' proteins we used remained unchanged up to the terminal ileum and that the AA composition of the endogenous protein was constant, regardless of the variable dietary factors. The protein associated to the NDF fraction was introduced in the model because it was likely to be recovered intact at the end of the ileum according to the restricted access of digestive enzymes to protein encapsulated by fibre [58].
However, dietary factors may cause changes not only in the amount of endogenous AA losses, but also in their AA composition. In particular, any change in bacterial $\mathrm{N}$ flow, which contributes to 20 to $50 \%$ of ileal $\mathrm{N}$ recovered at the end of the ileum of pigs fed cereal-based diets $[13,58]$, may cause changes in the AA composition of the digesta protein [6], and therefore, bias the estimates of endogenous losses.

Our ranking of cereal species for TD of AA was similar to previously reported references [12, 19, 20, 22, 34, 35]. However, in contradiction to our results, higher digestibility values in rye than in barley [53] and similar or even greater digestibility values in 
sorghum than in maize $[38,60]$ were also reported. The variability between batches possibly encountered within a cereal species $[19,36,41,60]$ may partly explain contradictory results across the studies.

Total endogenous $\mathrm{N}$ losses for the wheat, triticale, rye, barley, maize and sorghum based diets were estimated at 2.63, 3.10, 2.16, 2.27, 2.43 and $2.93 \mathrm{~g} \cdot \mathrm{kg}^{-1} \mathrm{DMI}$, respectively. By means of the same method, similar estimates of total endogenous $\mathrm{N}$ losses have been obtained for wheat, rye, barley and maize based diets offered to growing pigs $\left(2.85,2.60,2.60\right.$ and $\left.3.14 \mathrm{~g} \cdot \mathrm{kg}^{-1} \mathrm{DMI}\right)$ [34]. Using the homoarginine method, similar total endogenous $\mathrm{N}$ losses $\left(2.77 \mathrm{~g} \cdot \mathrm{kg}^{-1}\right.$ DMI) in 25-49 kg pigs fed a $93 \%$ barley diet were calculated [50]. However, clearly higher total endogenous $\mathrm{N}$ losses were measured by intravenous ${ }^{15} \mathrm{~N}$ dilution using ${ }^{15} \mathrm{~N}$-L-Leucine infusion, for pigs fed $94 \%$ wheat and barley diets (4.38 and $4.43 \mathrm{~g} \cdot \mathrm{kg}^{-1}$ DMI, respectively) [12] and for pigs fed a $90 \%$ barley diet $\left(6.4 \mathrm{~g} \cdot \mathrm{kg}^{-1} \mathrm{DMI}\right)$ [37]. A possible overestimation of total $\mathrm{N}$ endogenous losses determined by the $\mathrm{N}$ isotope dilution technique may explain part of these discrepancies [37].

We calculated the average basal endogenous $\mathrm{N}$ losses from 20 individual measurements, which were almost two times lower than the values reported in the literature [63]. Nevertheless, the reported range of variation $\left(2.22 \pm 0.88 \mathrm{~g} \mathrm{~N} \cdot \mathrm{kg}^{-1} \mathrm{DMI}\right)$ was not exceeded. Estimates of total endogenous $\mathrm{N}$ and AA losses $\left(\mathrm{g} \cdot \mathrm{kg}^{-1} \mathrm{DMI}\right)$ for rye and triticale were greater than the basal endogenous losses by 1.9 and 2.7 times, respectively (Tab. III). This implies that digesta of pigs fed a cereal based diet contain specific endogenous AA in addition to basal endogenous AA [49, 59]. As a consequence, $R D$ values exceeded TD values. The difference, which represents the specific endogenous AA losses as percentage of the AA content of the diet, ranged, for the sum of all AA, between 3.9 and 7.2 units for barley and triticale, respectively.

\subsection{Dietary factors affecting ileal digestibility and endogenous gut losses of $\mathrm{N}$ and $\mathrm{AA}$}

The partitioning of AA in digesta protein implies that protein present in the NDF fraction of all cereals, except sorghum, is only partially digested and absorbed prior to the end of the ileum. This may be caused by the restricted access of digestive enzymes to protein encapsulated by fibre [58]. Only $60 \%$ of $\mathrm{N}$ bound to NDF extracted from wheat bran was reported to be digested at the end of the ileum of growing pigs [58]. We calculated that on average $60 \%$ of $\mathrm{N}$ in NDF was digested before the end of the ileum in wheat and triticale, $45 \%$ in maize, and less than $20 \%$ in rye and barley. The high proportion of $\mathrm{N}$ bound to NDF in rye (Tab. I) and the presence of three layers in the aleurone of barley $[16,60]$ could be plausible factors contributing to the low TD and $\mathrm{RD}$ values in these species. This phenomenon may also explain the overall low $\mathrm{TD}$ and RD of lysine. Indeed, the functional proteins (albumins and globulins), rich in lysine, are located in the most fibrous part of the grain (aleurone cells) [8].

Total endogenous AA losses $\left(\mathrm{g} \cdot \mathrm{kg}^{-1}\right.$ $\mathrm{DMI}$ ) tended to increase with increase in the dietary concentration of ADF $\left(\mathrm{g} \cdot \mathrm{kg}^{-1} \mathrm{DM}\right)$ in wheat $(r=56, P<0.10)$, and were clearly greater with increase in the dietary concentrations of NDF or insoluble hemicellulose (NDF-ADF) in barley $(r=0.91, P<0.05$ and $r=0.98, P<0.01$, respectively). Except for barley, total endogenous AA losses increased with increase in the dietary content of $\operatorname{ADF}(r=0.57, P<0.001)$ (Fig. 1). An increase in endogenous $\mathrm{N}$ losses with increasing dietary NDF concentration was also observed with pigs fed semi-synthetic diets $[42,58]$. Many mechanisms may be involved: the direct stimulation of digestive secretion, the enhanced sloughing of epithelial cells, a modification of the rate of reabsorption or the alteration of the rate of passage through the intestinal tract [49]. Lower endogenous $\mathrm{N}$ losses in pigs fed 


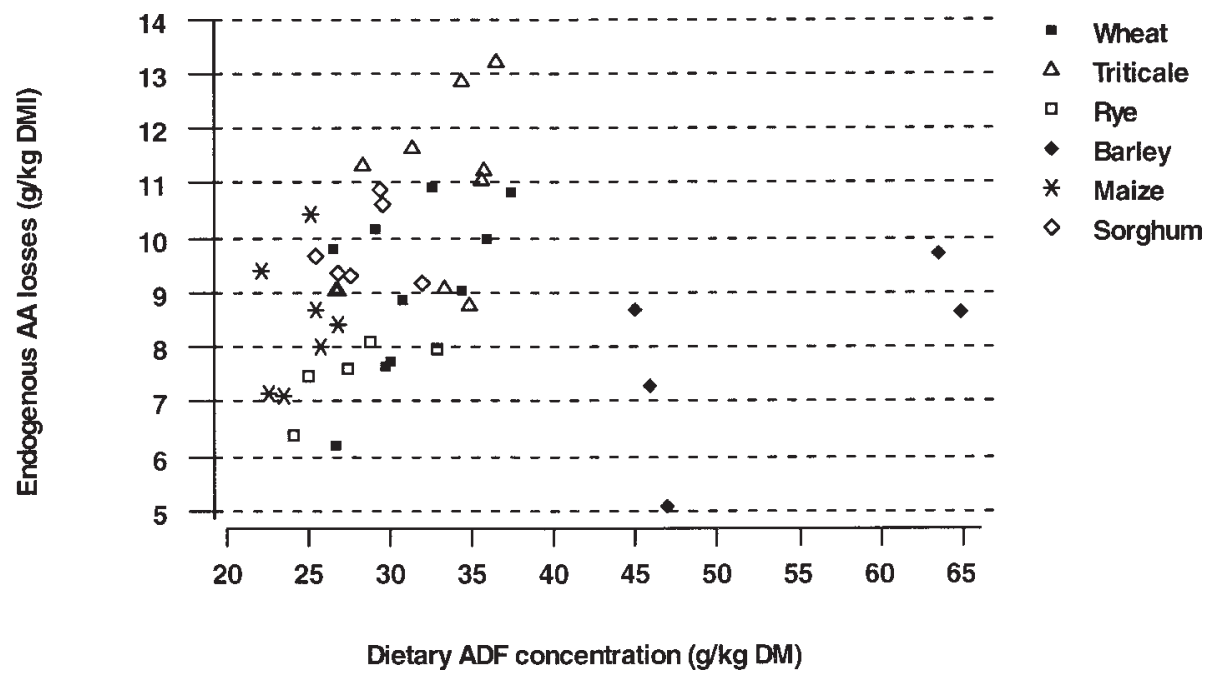

Figure 1. Total endogenous $\mathrm{AA}^{1}$ losses $\left(\mathrm{g} \cdot \mathrm{kg}^{-1} \mathrm{DM}\right.$ ingested) in relation to the $\mathrm{ADF}$ content in the cereal based diets $\left(\mathrm{g} \cdot \mathrm{kg}^{-1} \mathrm{DM}\right)$.

${ }^{1}$ Sum of all AA.

graded levels of CF from barley than from wheat were already reported elsewhere [12]. Lignin proportion in ADF is greater for wheat, triticale and rye than for barley (28 vs. $15 \%$ ADF) (Tab. I). Thus, fibre originating from wheat, triticale and rye might have been a more effective factor in increasing the ileal endogenous flow, due to a more pronounced mechanical effect enhancing the cells sloughing and (or) the adsorptive capacities of lignin, and thereby, a limited availability of some endogenous AA for absorption [4].

TD of AA and the analytical characteristics of the diets were poorly correlated. However, in triticale, TD of most AA decreased as CF and ADF contents of the diet increased $(r=-0.82(P<0.01)$ and $r=-0.73(P<0.05)$ for the sum of all AA, respectively). In wheat, TD of some AA and $\mathrm{CF}$ content of the diet were clearly correlated $(r=-0.70$ for the sum of all AA, $P<0.05)$. In sorghum, TD of most AA decreased as the ADL content of the diet increased $(r=-0.92$ for the sum of all AA, $P<0.01)$. This probably reflected the deleterious effect of fibre on TD of $\mathrm{N}$ and AA through an increase in total endogenous $\mathrm{N}$ losses and in the undigested dietary fraction. However, plant fibre consists of a number of different components and not only the dietary fibre concentration, but also its physico-chemical properties, might have affected the level of recovery of both endogenous and dietary $\mathrm{AA}$ at the terminal ileum.

In recent years, a special attention has been paid to arabinoxylans in wheat, triticale and rye, and to $\beta$-glucans in barley. These compounds may restrict the access to intracellular nutrients or raise the viscosity of the luminal content, and thereby limit the physical exposure of substrates to the digestive enzymes and to the intestinal wall [7]. The greater amounts of arabinoxylans present in rye as compared to wheat and triticale may contribute to the low digestibility of $\mathrm{N}$ and AA in this species [53]. Possibly, arabinoxylans in rye were involved in the restricted access of digestive enzymes to intracellular nutrients, causing a low digestibility of the protein bound to NDF. 
From 60 to $70 \% \beta$-glucans in barley grain is in a soluble form and would have little effect on $\mathrm{N}$ and AA digestibility due to the fact that they are degraded by the microflora naturally present in the small intestine of growing pigs [21, 29]. Our results also suggest that $\beta$-glucans had probably a limited impact on the re-absorption of endogenous secretions in barley. Besides, our data confirm the previously reported [36] lack of relevance of water extract relative viscosity for predicting ileal digestibility of $\mathrm{N}$ and AA in pigs.

Condensed tannins are generally considered responsible for the low nutrients digestibility in high-tannins sorghum compared to maize, as well as for the variability in ileal digestibility of $\mathrm{N}$ and AA encountered in this species [9]. These water soluble phenolic compounds are able to precipitate proteins either initially in the grain or in the digestive tract of the animal leading to an increase in both endogenous and dietary $\mathrm{N}$ losses [39, 41, 46]. Our analytical method might have underestimated the actual tannins content in our sorghum batches [11]. However, it was probably below the threshold level required for a significant effect on the recovery of AA of endogenous or dietary origins at the end of the ileum [47]. Actually, in low-tannins sorghum, protein digestibility would be mainly affected by the structure of prolamins [15]. These proteins being located in the starchy endosperm and making up to $80 \%$ of the total protein in the grain [8], this would be consistent with the recovery of the whole dietary protein, and not the residual protein of NDF, in the digesta of pigs fed sorghum.

Protease inhibitors are present in cereals, mainly, barley, rye and triticale [28]. When fed at a low concentration, they may induce an increase in endogenous $\mathrm{N}$ losses [3]. However, there is no evidence from the literature that protease inhibitors influence ileal digestibility of AA in cereals fed to pigs [53]. Phytate accounts for $85 \%$ of phosphorus stored in cereals. It may form complexes not only with minerals but also with dietary proteins, impairing their digestibility. However, very little complexing between wheat protein and phytate was observed and its deleterious effect on protein digestibility in cereals remains uncertain [16, 61].

Finally, bearing in mind the TD of $\mathrm{N}$ and AA we ranked the species in the following order: wheat, maize, triticale, barley, sorghum and rye. Differences among the species were related to different rates of recovery of both endogenous and dietary $\mathrm{N}$. Except in the case of barley, specific endogenous $\mathrm{N}$ losses excreted by pigs fed cereals increased with graded concentrations of ADF. A part of AA "encapsulated" in fibre represented, in most cases, the dietary undigested fraction. However, further studies on the effects of specific fractions of fibre or protein intrinsic properties on the ileal endogenous and dietary $\mathrm{N}$ losses would be desirable for understanding the variability among as well as within species.

\section{ACKNOWLEDGEMENTS}

Some of the results were obtained with the financial support of the French Ministry of Education and Research (ACTA programme) and the European Commission (CAMAR CT 91-0112). The work was performed in collaboration with Mengvoeder UT-Delfia (NL), Suomen Rehu (SF) and Sanofi Santé Nutrition Animale (F). The authors wish to thank the staffs of the ITCF pig unit research, the ITCF laboratory, the ITCF methods department and the Eurolysine laboratory for their technical assistance. Also R. Pinot (Sanofi Santé Nutrition Animale, F), D. Sauvant (INA-PG, Paris, F) and G. Rychen (ENSAIA, Nancy, F) are gratefully acknowledged for their advise in preparing this paper.

\section{REFERENCES}

[1] AFNOR, Dosage des tanins, NF V 03-751, Association Française de Normalisation, ParisLa Défense, 1985.

[2] Bach Knudsen K.E., Carbohydrates and lignin content of plant materials used in animal feeding, Anim. Feed Sci. Technol. 67 (1997) 319-338. 
[3] Barth C.A., Lunding B., Schmitz M Hagemeister H., Soybean trypsin inhibitor(s) reduce absorption of exogenous and increase loss of endogenous protein in miniature pigs, J. Nutr. 123 (1993) 2195-2200.

[4] Bergner H., Lück M., Müller J., Untersuchung zur Sorption von Aminosaüren an Diätkomponenten, Arch. Tierernähr. (Berlin) 31 (1981) 265-271.

[5] Bodin J.C., McMillan E., Maillard R., van Kempen T., Williams P.E.V., Effect of time post-surgery on the measurement of ileal digestibility in ileal rectal anastomosed pigs, in: Proc. British Soc. Anim. Sci., Scarborough, UK, March 1998, p. 168.

[6] Caine W.R., Tamminga S., Sauer W.C., Verstegen M.W.A., Schulze H., Bacterial contributions to total and endogenous recoveries of nitrogen and amino acids in ileal digesta of newly weaned piglets fed protease-treated soybean meal, Livest. Prod. Sci. 57 (1999) 147-157.

[7] Chesson A., Feed enzymes, Anim. Feed Sci. Technol. 45 (1993) 65-79.

[8] Chung O.K., Pomeranz Y., Amino acids in cereal proteins and protein fractions, in: Finley J.W., Hopkins D.T. (Eds.), Digestibility and amino acids availability in cereals and oilseeds, American Association of Cereal Chemists, St-Paul, Minnesota, USA, 1985, pp. 65-103.

[9] Cousins B.W., Tanksley T.D. Jr., Knabe D.A., Zebrowska T., Nutrient digestibility and performance of pigs fed sorghum varying in tannin concentration, J. Anim. Sci. 53 (1981) 1524-1537.

[10] CVB, Veevoedertabel 1998, Centraa Veevoederbureau, Lelystad, The Netherlands, 1998.

[11] Daiber K.H., Enzyme inhibition by polyphenols of sorghum grain and malt, J. Sci. Food Agric. 26 (1975) 1399-1411.

[12] de Lange C.F.M., Souffrant W.B., Sauer W.C. Real ileal protein and amino acid digestibilities in feedstuffs for growing pigs as determined with the ${ }^{15} \mathrm{~N}$-isotope dilution technique, J. Anim. Sci. 68 (1990) 409-418.

[13] Dierick N.A., Decuypere J.A., Vervaeke I.J., Henderickx H.K., Digestion iléale et fécale de la matière sèche, des protéines et des acides aminés de quelques rations conventionnelles pour les porcs à l'engrais, Rev. Agric. (Bruxelles) 36 (1983) 1713-1726.

[14] Duvaux C., Guilloteau P., Toullec R., Sissons J.W., A new method for estimating the proportions of different proteins in a mixture using amino acid profiles: Application to undigested proteins in the preruminant calf, Ann. Zootech. 39 (1990) 9-18.

[15] Elkin R.G., Freed M.B., Hamaker B.R., Zhang Y., Parsons C.M., Condensed tannins are only partially responsible for variations in nutrien digestibilities of sorghum grain cultivars, J. Agric. Food Chem. 44 (1996) 848-853.
[16] Evers A.D., Blakeney A.B., O'Brien L., Cerea structure and composition, Aust. J. Agric. Res. 50 (1999) 629-650.

[17] Fan M.Z., Sauer W.C., Hardin R.T., Lien K.A. Determination of apparent ileal digestibility in pigs: Effect of dietary amino acid level, J. Anim. Sci. 72 (1994) 2851-2859.

[18] Fuller M.F., Methodologies for the measurement of digestion, in: Verstegen M.W.A., Huisman J., den Hartog L.A. (Eds.), Proc. 5th Intern. Symp. on Digestive Physiology in Pigs, EAAP Publication No. 54, Pudoc, Wageningen, The Netherlands, April 24-26, 1991, pp. 273-288.

[19] Fuller M.F., Cadenhead A., Brown D.S., Brewer A.C., Carver M., Robinson R., Varietal differences in the nutritive value of cereal grains for pigs, J. Agric. Sci. (Camb.) 113 (1989) 149-163.

[20] Furuya S., Kaji Y., Additivity of the apparen and true ileal digestible amino acid supply in barley, maize, wheat or soya-bean meal based diets for growing pigs, Anim. Feed Sci. Technol. 32 (1991) 321-331.

[21] Graham H., Hesselman K., Aman P., Influence of $\beta$-glucanase supplementation on digestion of a barley-based diet in the pig gastrointestinal tract, Nutr. Rep. Intern. 34 (1986) 1089-1096.

[22] Green S., Bertrand S.L., Duron M.J.C., Maillard R.A., Digestibility of amino acids in maize, wheat and barley meal measured in pigs with ileo-rectal anastomosis and isolation of the large intestine, J. Sci. Food Agric. 41 (1987) 29-43.

[23] Grosjean F., Saulnier L., Maupetit P., Beaux M.F., Flatres M.C., Magnin M., Le Pavec P. Victoire C., Variability of wheat and other cereal water extract viscosity. 1. Improvements in measuring viscosity, J. Sci. Food Agric. 79 (1999) 116-122.

[24] Grosjean F., Maupetit P., Beaux M.F., Variability of wheat and other cereal water extract viscosity. 2. Range and causes of variation, J. Sci. Food Agric. 79 (1999) 123-130.

[25] Gualtieri M., Rapaccini S., Sorghum grain in poultry feeding, World's Poult. Sci. J. 46 (1990) 246-254.

[26] Hess V., Sève B., Effects of body weight and feed intake level on basal ileal endogenous losses in growing pigs, J. Anim. Sci. 77 (1999) 3281-3288.

[27] Hodgkinson S.M., Moughan P.J., Reynolds G.M., Effect of live weight on endogenous ileal nitrogen and amino acid excretion in the growing pig, in: Cranwell P.D. (Ed.), Manipulating Pig Production VI. Proc. 6th Biennal Conf. Australasian Pig Sci. Assoc., Canberra, ACT December 7-10, 1997, pp. 235-236.

[28] Huisman J., van der Poel A.F.B., Verstegen M.W.A., van Weerden E.J., Antinutritional factors (ANF) in pig production, World Rev. Anim. Prod. 25 (1990) 77-82. 
[29] Jensen M.S., Bach Knudsen K.E., Inborr J., Jakobsen K., Effect of $\beta$-glucanase supplementation on pancreatic enzyme activity and nutrient digestibility in piglets fed diets based on hulled and hulless barley varieties, Anim. Feed Sci. Technol. 72 (1998) 329-345.

[30] Jondreville C., van den Broecke J., Gâtel F., van Cauwenberghe S., Ileal digestibility of amino acids in feedstuffs for pigs, EurolysineITCF, Paris, France, 1995, 53 p.

[31] Jondreville C., van den Broecke J., Grosjean F., Van Cauwenberghe S., Gâtel F., Ileal true digestibility of amino acids in wheat milling byproducts for pigs, Ann. Zootech. 49 (2000) 1-11.

[32] Laplace J.P., Darcy-Vrillon B., Perez J.P., Henry Y., Giger S., Sauvant D., Associative effect of feeding different protein-free diets between two fibre sources on ileal and overall digestibilities of amino acids, energy and cell-wall components in growing pigs, Brit. J. Nutr. 61 (1989) 75-87.

[33] Laplace J.P., Souffrant W.B., Hennig U., Chabeauti E., Février C., Measurement of precaecal dietary protein and plant cell wall digestion in pigs: Comparison of four surgical procedures for ileorectal anastomosis, Livest. Prod. Sci. 40 (1994) 313-328.

[34] Lechevestrier Y., Digestion et absorption des acides aminés dans l'intestin grêle du porc. Effets de la composition des protéines alimentaires, de leurs propriétés physiques et des facteurs antinutritionnels, Thèse de doctorat, Institut National Agronomique Paris-Grignon, 1996, $161 \mathrm{p}$.

[35] Leterme P., Thielemans C., Bodart C., Baudart E., Thewis A., Valeur nutritive et digestibilité apparente iléale et fécale du triticale, du froment et de l'escourgeon chez le porc, Rev. Agric. (Bruxelles) 42 (1989) 305-316.

[36] Lewis F.J., McEvoy J., McKracken K.J., Lack of relationship between wheat in vitro viscosity and digestibility parameters for pigs, in: Proc. British Soc. Anim. Sci., Scarborough, UK, March, 1998, p. 32.

[37] Lien K.A., Sauer W.C., Mosenthin R., Souffrant W., Dugan M.E.R., Evaluation of the ${ }^{15} \mathrm{~N}$ isotope dilution technique for determining the recovery of endogenous protein in ileal digestion of pigs: Effect of dilution in the precursor pool for endogenous nitrogen secretion, J. Anim. Sci. 75 (1997) 148-158.

[38] Lin F.D., Knabe D.A., Tanksley T.D. Jr., Apparent digestibility of amino acids, gross energy and starch in corn, sorghum, wheat, barley, oat groats and wheat middlings for growing pigs, J. Anim. Sci. 64 (1987) 1655-1663.

[39] Lizardo R., Peiniau J., Aumaitre A., Effect of sorghum on performance, digestibility of dietary components and activities of pancreatic and intestinal enzymes in the weaned piglet, Anim. Feed Sci. Technol. 56 (1995) 67-82.
[40] Low A.G., Digestibility and availability of amino acids from feedstuffs for pigs: a review, Livest. Prod. Sci. 9 (1982) 511-520.

[41] Mariscal-Landin G., Facteurs de variation de l'utilisation digestive des acides aminés chez le porc, Thèse de Doctorat, Université de Rennes I, 1992, $134 \mathrm{p}$.

[42] Mariscal-Landin G., Sève B., Colleaux Y., Lebreton Y., Endogenous amino nitrogen collected from pigs with end-to-end ileorectal anastomosis is affected by the method of estimation and altered by dietary fiber, J. Nutr. 125 (1995) 136-146.

[43] Mc Cleary B.V., Gibson T.S., Allen H., Gams T.C., Enzymic hydrolysis and industrial importance of barley $\beta$-glucans and wheat flour pentosans, Starch/Stätke 38 (1986) 433-437.

[44] Métayer J.P., Grosjean F., Castaing J., Study of variability in French cereals, Anim. Feed Sci. Technol. 43 (1993) 87-108.

[45] MINITAB, MINITAB reference manual (release 11), MINITAB Inc., USA, 1996.

[46] Mitaru B.N., Reichert R.D., Blair R., The binding of dietary protein by sorghum tannins in the digestive tract of pigs, J. Nutr. 114 (1984) 1787-1796.

[47] Mosenthin R., Sauer W.C., Lien K.A., de Lange C.F.M., Apparent, true and real protein and amino acid digestibilities in growing pigs fed two varieties of fababeans (Vicia Faba L.) different in tannin content, J. Anim. Physiol. Anim. Nutr. 70 (1993) 253-265.

[48] NRC, Nutrient requirements of swine, 10 th rev. Ed. National Academy of Sciences-National Research Council, Washington, DC, 1998, 198 p.

[49] Nyachoti C.M., de Lange C.F.M., McBride B.W., Schulze H., Significance of endogenous gut nitrogen losses in the nutrition of growing pigs: A review, Can. J. Anim. Sci. 77 (1997) 149-163.

[50] Nyachoti C.M., de Lange C.F.M., Schulze H., Estimating endogenous amino acid flows at the terminal ileum and true ileal amino acid digestibilities in feedstuffs for growing pigs using the homoarginine method, J. Anim. Sci. 75 (1997) 3206-3213

[51] Picard M., Bertrand S., Genin F., Maillard M., Digestibilité des acides aminés : Intérêt de la technique du shunt iléo-rectal chez le porc, Journées Rech. Porcine en France 16 (1984) 355-360.

[52] Rademacher M., Sauer W.C., Jansman A.J.M., Standardized ileal digestibility of amino acids in pigs. The new system, Degussa-Hüls AG Frankfurt/Main, Germany, 1999, 20 p.

[53] Rakowska M., Zebrowska T., Neumann M., Medynska K., Raczynska-Bojanowska K., The apparent ileal and fecal digestibilities of amino acids and carbohydrates of rye, barley and triticale grains in pigs, Arch. Anim. Nutr. (Berlin) 40 (1990) 695-701. 
[54] Rouau X., Surget A., A rapid semi automated method for the determination of total and water extractable pentosans in wheat flours, Carbohydr. Polym. 24 (1994) 123-132.

[55] RPAN, Rhodimet ${ }^{\mathrm{TM}}$ Nutrition Guide. Formulation des aliments en acides aminés digestibles, $2^{\mathrm{e}}$ ed., Rhône Poulenc Animal Nutrition, Antony, France, 1993, 54 p.

[56] SAS, SAS/STAT ${ }^{\circledR}$, User's Guide (4th ed., Vol. 2), SAS Inst. Inc., Cary, NC, 1990

[57] Schulze H., Makkink C.A., Le Guen M.P. Verstegen M.W.A, Endogenous N losses as measured by two independent methods, in: Verstegen M.W.A., den Hartog L.A., van Kempen G.J.M., Metz J.H.M. (Eds.), Proc. 1st Intern. Symp. on Nitrogen Flow in Pig Production and Environmental Consequences, Wageningen, The Netherlands, 8-11 June, 1993, pp. 62-69.

[58] Schulze H., van Leeuwen P., Verstegen M.W.A Huisman J., Souffrant W.B., Ahrens F., Effect of level of Dietary Neutral Detergent Fiber on ileal apparent digestibility and ileal nitrogen losses in pigs, J. Anim. Sci. 72 (1994) 2362-2368.

[59] Sève B., Henry Y., Protein utilization in non ruminants, in: Nunes A.F., Portugal A.V., Costa J.P., Ribeiro J.R. (Eds.), Proc. 7th Symp. on Protein Metabolism and Nutrition, Vale de
Santarém, Portugal, 24-27 May 1995, EAAP Pub. No. 81, 1996, pp. 59-82.

[60] Taverner M.R., Hume I.D., Farell D.J., Availability to pigs of amino acids in cereal grains. 2 . Apparent and true ileal availability, Brit. J. Nutr. 46 (1981) 159-171.

[61] van Barneveld R.J., Chemical and physical characteristics of grains related to variability in energy and amino acid availability in pigs: A review, Aust. J. Agric. Res. 50 (1999) 667-687.

[62] WPSA, European Amino Acid Table, 1st ed. in: Janssen W.M.M.A., Ingelaat F.B.M., Shaper S., McNab J. (Eds.), World Poultry Science Association Publication, Beekbergen, The Netherlands, 1992, $123 \mathrm{p}$

[63] Wünsche J., Herrmann U., Meinl M., Hennig U., Kreienbring F., Zwierz P., Einfluss exogener Faktoren auf die präzäkale Nährstoff- und Aminosaürenresorption, ermittelt an Schweinen mit ileo-rektal Anastomosen. 1. Mitteilung: Einfluss des Zerkleinerungsgrades von Getreide, Arch. Anim. Nutr. (Berlin) 37 (1987) 745-764.

[64] Yin Y.L., Huang R.L., Zhong H.Y., Comparison of ileo-rectal anastomosis and the conventional method for the measurement of ileal digestibility of protein sources and mixed diets in growing pigs, Anim. Feed Sci. Technol. 42 (1993) 297-308. 